\title{
ODNOS PREBIVALSTVA SLOVENSKIH ALPSKIH TURISTIČNIH KRAJEV DO TURIZMA IN NJEGOVIH UČINKOV
}

\author{
dr. Dejan Cigale
}

Oddelek za geografijo, Filozofska fakulteta Univerze v Ljubljani

Aškerčeva 2, SI- 1000 Ljubljana

e-mail: dejan.cigale@ff.uni-lj.si

Strokovni članek

COBISS 1.04

\section{Izvleček}

Namen prispevka je bil ugotoviti, kako domačini zaznavajo pozitivne in negativne učinke turizma v slovenskem alpskem svetu ter, kako percepcija učinkov vpliva na njihov odnos do turizma in turističnega razvoja. $\mathrm{V}$ ta namen je bila izvedena anketna raziskava v petih turističnih krajih. Kljub razlikam med kraji so bile ugotovljene številne skupne značilnosti. Povsod prevladuje pozitiven odnos do turizma. V splošnem so bili kot najpomembnejši vrednoteni ekonomski, kot najmanj pomembni pa socio-kulturni učinki turizma.

Ključne besede: Alpe, Slovenija, turizem, rekreacija, učinki turizma, percepcija učinkov turizma

\section{ATTITUDE OF THE POPULATION OF SLOVENIAN ALPINE TOURIST RESORTS TOWARD TOURISM AND ITS IMPACTS}

\begin{abstract}
The aim of this paper was to find out how the local inhabitants perceive positive and negative tourism impacts in Slovenian alpine areas and how this perception influence their attitude toward tourism. A questionnaire survey was undertaken in five different tourist resorts. Despite the differences between resorts there are many similarities in perception of tourism impacts. In all cases positive attitudes toward tourism prevail. In general the economic impacts were perceived as the most important and the socio-cultural impacts as the least important.
\end{abstract}

Key words: Alps, Slovenia, tourism, recreation, impacts of tourism, perception of tourism impacts 


\section{UVOD}

Alpe so pomembno svetovno ciljno turistično območje in tudi slovenski alpski svet spada med turistično bolj razvita območja v Sloveniji. Turizem ima na tem območju že precejšnjo tradicijo, zares množičen pa je postal v drugi polovici 20. st. Znotraj slovenskega alpskega sveta so prisotne precejšnje razlike v obsegu turističnega obiska, večina turističnih krajev z večjim turističnim obiskom je na območju Julijskih Alp. Na drugi strani so razmeroma obsežna območja, kjer skorajda ni turističnih nastanitvenih zmogljivosti in kjer je tudi enodnevni turistični obisk razmeroma skromen. Čeprav je vloga zimskega turizma nadpovprečno pomembna, ima večina turističnih krajev več obiska poleti.

Ožje območje slovenskega alpskega sveta ne sodi med gosteje poseljena območja Slovenije. Med bolj pomembnimi turističnimi kraji ima samo Bled več kot 5000 prebivalcev. Tako je v številnih krajih z večjim turističnim obiskom na višku sezone število obiskovalcev primerljivo s številom stalnih prebivalcev (ali celo večje). Zaradi relativno manjših okoljskih in družbenih vplivov stalnega prebivalstva in drugih dejavnosti so tudi spremembe, do katerih je prihajalo zaradi turizma, toliko pomembnejše in toliko bolj očitne.

Različni učinki na naravo in družbo, ki jih je povzročil turistični razvoj, so marsikje zaradi intenzivnosti vsaj lokalno precej pomembni, ravno tako pa je pomembno, kako te učinke doživlja in vrednoti prebivalstvo turističnih območij, saj je od tega odvisen tudi njihov odnos do nadaljnjega razvoja turizma. Poleg tega je z vidika prizadevanj za trajnostni razvoj turizma zelo pomembno, da so z njim zadovoljni tudi domačini, ki od turizma »pričakujejo napredek, toda brez slabšanja kakovosti njihovega življenja« (Razvojni načrt in usmeritve 2007).

Slika 1: Vloga učinkov turizma pri oblikovanju odnosa lokalnega prebivalstva do prihodnjega turističnega razvoja

Figure 1: The role of tourism impacts in influencing the attitude of local population toward future tourism development

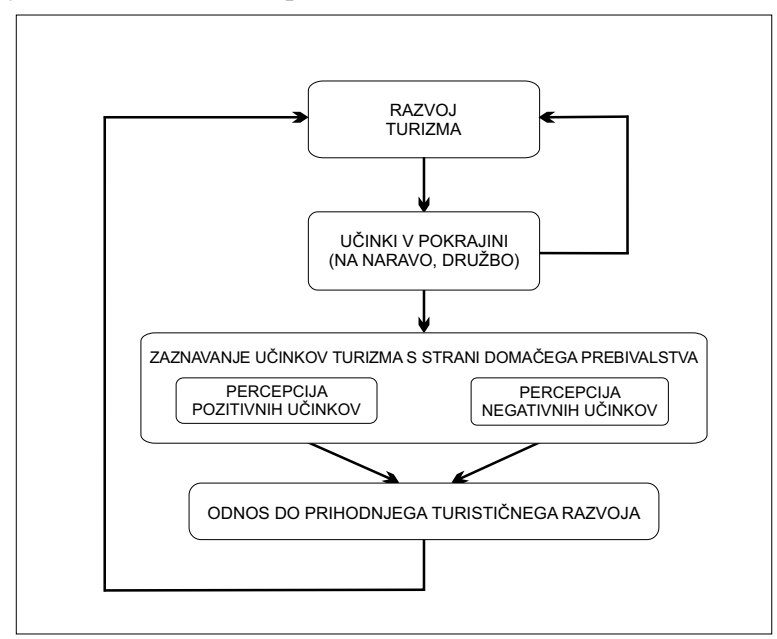


Namen pričujoče raziskave je bil ugotoviti, kako domačini zaznavajo pozitivne in negativne učinke turizma v slovenskem alpskem svetu ter kako percepcija učinkov vpliva na njihov odnos do turizma in turističnega razvoja (slika 1). Pri tem nas je zanimalo tudi, kateri učinki turizma so po mnenju domačinov najbolj pomembni. Preučevanje je bilo del širše raziskave, ki se je posvečala učinkom rekreacije in turizma v slovenskem alpskem svetu, kar je tudi pogojevalo uporabljene metode. $\mathrm{Na}$ tem mestu bodo zaradi omejenega prostora predstavljeni lenekateri pomembnejši rezultati. Mnenje prebivalstva smougotavljalis pomočjo anketiranja, podrobnosti o uporabljenih metodah pa so predstavljene v nadaljevanju.

Na naslednjih straneh bomo najprej na kratko povzeli nekatere ugotovitve literature, ki se je posvečala problematiki percepcije turizma in njegovih učinkov pri domačem prebivalstvu, glavna pozornost pa bo namenjena predstavitvi rezultatov našega anketiranja.

\section{NEKATERI POMEMBNEJŠI REZULTATI RAZISKAV O PERCEPCIJI UČINKOV TURIZMA}

S problematiko odnosa prebivalstva turističnih območij do turizma in turistov se je ukvarjala že cela vrsta raziskav, saj poznavanje teh vprašanj ni zanimivo zgolj z akademskega vidika, temveč ima tudi praktičen pomen za planiranje razvoja na turističnih območjih.

Glede razlage odnosa domačinov do turizma in turistov so različni avtorji (npr. Fredline in Faulkner 2000; Gilbert in Clark 1997; Ryan in sod. 1998; Tosun 2002) pogosto navajali Doxeyev model, po katerem se skozi različne faze turističnega razvoja spreminja odnos domačega prebivalstva do turizma in turistov, ki postaja čedalje bolj negativen oziroma čedalje manj naklonjen turistom in turizmu. Slabost tega modela je, da obravnava lokalno prebivalstvo kot homogeno skupino, ki se enovito odziva na turistični razvoj, kar v resnici ne velja (na kar opozarjajo npr. Brunt in Courtney 1999, Saveriades 2000 in drugi). Kot sredstvo za razlago percepcije učinkov turizma je bila pogosto uporabljena tudi teorija socialne izmenjave (npr. Andereck in sod. 2005; Chen 2001; Jurowski in Gursoy 2004; Lee in Back 2003; McGehee in Andereck 2004; Perdue in sod. 1999). Ne glede na različne metodološke okvire pa so rezultati različnih raziskav pokazali predvsem na veliko raznolikost in kompleksnost odnosov lokalnega prebivalstva do turizma.

Kljub velikim razlikam v dobljenih ugotovitvah so v splošnem njihovi rezultati (npr. Andriotis in Vaughan 2003; Brunt in Courtney 1999; Coles in Shaw 2003; Gezici 2005; Haralambopoulos in Pizam 1996; Kariel in Kariel 1982; Lawson in sod. 1998; McGehee in Andereck 2004; Puczkó in Rátz 2000; Rátz 2002; Tosun 2002) pokazali, da domačini na turističnih območjih sicer opažajo negativne učinke turizma, vendar je podpora turizmu in turistični dejavnosti praviloma med njimi zelo velika. Ne glede na to pa so bila v nekaterih primerih mnenja domačinov glede vloge turizma vendarle bolj deljena (npr. Meyrat 1983; citirano po Müller 1986).

Splošno vrednotenje turizma zabriše vlogo posameznih dejavnikov in vplivov, med katerimi so praviloma tako pozitivni kot negativni. Večina prebivalcev turističnih krajev vidi kot pozitivne zlasti ekonomske učinke turizma (npr. Andriotis in Vaughan 2003; Coles in Shaw 2003; Haralambopoulos in Pizam 1996; Kariel in Kariel 1982; Ryan in sod. 1998; 
Tosun 2002). Tako so prebivalci turističnih območij opažali pozitivne učinke turizma na zaposlitvene priložnosti (Andriotis in Vaughan 2003; Coles in Shaw 2003; Haralambopoulos in Pizam 1996; Tosun 2002) in davčne prihodke (Haralambopoulos in Pizam 1996; McGehee in Andereck 2004; Tosun 2002), osebne dohodke, življenjski standard in odnos do dela (Haralambopoulos in Pizam 1996). Pogosto so tudi menili, da so službe v turizmu zaželene ali zelo zaželene (Haralambopoulos in Pizam 1996; McGehee in Andereck 2004; Tosun 2002).

Na drugi strani spremljajo razvoj turizma tudi negativni pojavi. Eden izmed njih je tudi porast cen, ki je deležen zelo negativnega odziva domačinov (npr. Haralambopoulos in Pizam 1996). Pri tem je še posebej negativno vrednoten porast cen zemljišč in nepremičnin (Kariel in Kariel 1982; Snaith in Haley 1999). Rezultati Brunta in Courtneya (1999) kažejo, da imajo lahko prebivalci turističnih krajev precej mešana mnenja tudi o s turizmom povezanih zaposlitvenih priložnostih.

Turizem s sabo prinaša številne in zelo raznolike socio-kulturne učinke, ki jih kot različno intenzivne občutijo tudi domači prebivalci, prav tako pa jih tudi zelo različno vrednotijo. Raziskava z območja avstrijskih Alp (Kariel in Kariel 1982) navaja, da so kot posledica razvoja turizma domačini začeli prihajati v stik z idejami iz širšega sveta. Pred prihodom turizma jim je bil npr. koncept prostega časa in odhoda na dopust tako rekoč neznan. $\mathrm{Na}$ drugi strani se je zaradi razvoja turizma in rasti dohodkov opazno zmanjšala skrb za blagostanje skupnosti kot celote in sodelovanje med prebivalci, lokalni dialekti, navade in manj stresen način življenja pa so začeli izumirati. Podobno diferenciran odnos domačinov do socio-kulturnih učinkov turizma kaže tudi vrsta drugih raziskav. Razvoj turizma lahko vpliva na spremenjeno vlogo žensk v družbi (Haralambopoulos in Pizam 1996). Turizem je v številnih primerih močno vplival tudi na družinsko življenje (Brunt in Courtney 1999). Haralambopoulos in Pizam (1996) sta npr. ugotavljala, da je po mnenju anketirancev turizem vplival na povečano gospodarsko neodvisnost mlajših odraslih oseb v družini, na povečano število njihovih potovanj v tuje države in na ustanavljanje novih domov po poroki. Precejšnje pozornosti raziskovalcev je bil deležen vpliv turizma na povečanje kriminala, ugotovitve o s tem povezanem mnenju domačega prebivalstva pa so bile precej različne (npr. Brunt in Courtney 1999; Haralambopoulos in Pizam 1996; Lawson in sod. 1998; Ryan in sod. 1998; Snaith in Haley 1999; Tosun 2002).

Lokalno prebivalstvo se sooča tudi z raznovrstnimi učinki turizma na okolje, ki jih različno zaznava in vrednoti (npr. Andriotis 2005; Baysan 2001; Bestard in Nadal 2007; Padilla y Sotelo in Luna Moliner 2003; Ponce Sánchez, 2004a; Ponce Sánchez 2004b). Njihov značaj in pomen sta odvisna tako od pokrajinskih značilnosti kot od značilnosti turističnega razvoja, pri tem pa gre za onesnaževanje posameznih pokrajinskih sestavin, hrup, odmetavanje odpadkov, vizualno degradacijo pokrajine in druge negativne vplive. $\mathrm{V}$ številnih primerih je bil za domačine najbolj moteč vpliv avtomobilskega prometa (npr. Brunt in Courtney 1999; Coles in Shaw 2003; Gunce 2003; Kariel in Kariel 1982; Lawson in sod. 1998; McGehee in Andereck 2004; Puczkó in Rátz 2000; Snaith in Haley 1999; Upchurch in Teivane 2000).

Na osnovi omenjenih študij lahko zaključimo, da med prebivalstvom turističnih območij $\mathrm{v}$ večini primerov prevladuje pozitiven odnos do turizma, pa tudi do turističnega razvoja $\mathrm{V}$ 
prihodnje. To pa vendarle ne pomeni, da domače prebivalstvo ne opaža njegovih negativnih učinkov. Podoba percepcije turizma in odnosa do njega je namreč bistveno bolj diferencirana in odvisna od konkretnih razmer. Kljub temu, da domačini v splošnem priznavajo pozitivne učinke turizma, so lahko negativne plati turističnega razvoja za znaten del domačega prebivalstva zelo moteče.

\section{ANKETIRANJE PREBIVALSTVA V IZBRANIH NASELJIH SLOVENSKEGA ALPSKEGA SVETA}

Z anketo smo želeli izvedeti kaj več o odnosu domačega prebivalstva do turizma, oziroma do turističnega razvoja $\mathrm{v}$ njihovem kraju, hkrati pa pridobiti dodatne informacije tudi o vplivih in učinkih turizma na območju slovenskega alpskega sveta, oziroma na območju naselij, izbranih za anketiranje. Pri tem smo želeli dobiti odgovore na naslednja vprašanja:

- kakšen je odnos stalnih prebivalcev do turizma in sprememb, ki jih je prinesel s sabo, oziroma kako vrednotijo te spremembe;

- $\quad$ kateri so učinki, ki jih domačini vrednotijo kot najpomembnejše;

- kakšno je mnenje domačega prebivalstva o razvoju turizma v prihodnje.

Vprašalnikjesestavljalovečvsebinskihsklopov. Prviinnajobsežnejši sklopsopredstavljale trditve o raznovrstnih učinkih turizma v samem turističnem kraju. Anketirancem smo dali možnost, da povedo, ali se z določeno trditvijo popolnoma strinjajo, deloma strinjajo, se glede nje ne morejo odločiti, se v glavnem ne strinjajo ali pa se z njo sploh ne strinjajo.

Trditve so bile razdeljene $v$ več skupin. Tako se je prvih deset nanašalo na različne pozitivne učinke turizma, naslednjih šestnajst pa na negativne posledice turizma. Tretja skupina trditev se je nanašala na prihodnji razvoj turizma v kraju.

Poleg tega smo v vprašalnik vključili še tri vprašanja odprtega tipa, s pomočjo katerih smo želeli ugotoviti, kateri pozitivni in negativni učinki turizma so po mnenju anketirancev najpomembnejši in jim dati priložnost, da povedo v zvezi z vplivi turizma in s turizmom nasploh tudi kaj, čemur v vprašalniku nismo namenili ustrezne pozornosti.

$\mathrm{Na}$ koncu smo v vprašalnik vključili še nekaj vprašanj, ki so se nanašala na socio-demografske značilnosti anketirancev.

Zaradi omejenih možnosti ter širšega konteksta raziskave smo se odločili, da bomo anketiranje izvedli le v nekaj izbranih naseljih. Ker je vrednotenje vplivov in učinkov turizma močno odvisno od intenzivnosti in značilnosti turistične rabe (ponudbe in povpraševanja), smo anketo izvedli v naseljih $\mathrm{z}$ različno intenzivnostjo in naravo turizma (glede na vrste turizma, obstoječo turistično opremljenost, odnos med številom stalnih prebivalcev in turistov, sezonski potek turističnega obiska).

Naselja je bilo treba izbrati na takšen način, da bodo ugotovitve dovolj reprezentativne tudi za širši prostorski nivo. To pomeni, da so morala biti izbrana naselja z vidika obravnavane problematike dovolj značilna za slovenski alpski svet v celoti, na drugi strani pa so morale biti med njimi zadostne razlike, da bo z njihovo pomočjo mogoče dobiti pregled nad čim širšim spektrom učinkov turizma in rekreacije. 
Pri izboru naselij so igrali vlogo naslednji dejavniki:

- upoštevali smo podatke o intenziteti turističnega obiska in razmerju med turisti in stalnimi prebivalci ter sezonski koncentraciji turizma;

- upoštevali smo podatke o prostočasni ponudbi (možnosti za izvajanje različnih prostočasnih dejavnosti);

- poskušali smo zajeti prostorsko ločena območja z različnimi rekreacijskimi zaledji, z določenimi razlikami v pokrajinskih (tako naravnih kot družbenih) značilnostih, ki so pomembne $\mathrm{z}$ vidika rekreacije in turizma (možnosti za ukvarjanje $\mathrm{z}$ določenimi prostočasnimi značilnostmi, različne družbenogeografske razmere, pokrajinska podoba), z različno dostopnostjo v odnosu do bližnjih večjih prebivalstvenih središč;

- poskušali smo zajeti kraje z različno razvitim turizmom in v različnih fazah turističnega razvoja, s čimer so praviloma povezani tudi drugačni učinki turizma na pokrajino.

Pri izboru smo se tako odločili za naselja, ki se po značilnostih dosedanjega turističnega razvoja med sabo dovolj razlikujejo. Na ta način smo se želeli izogniti temu, da bi zaradi izbora preveč podobnih turističnih krajev zajeli le določene vrste učinkov turizma, oziroma o njih dobili preveč enostransko podobo. Na osnovi zgoraj navedenih dejavnikov smo se odločili, da bomo anketiranje izvedli v naseljih Kranjska Gora, Podkoren, Gozd Martuljek, Zgornje Jezersko in Bovec. Ta naselja ležijo na treh med sabo dokaj oddaljenih območjih v porečjih Soče, Save Dolinke in Kokre. Med njimi sta tudi dve mestni naselji, in sicer Kranjska Gora ter Bovec (Pavlin in sod. 2004).

\section{Preglednica 1: Nekateri podatki o turizmu v izbranih turističnih krajih}

Table 1: Some data on tourism in selected resorts

\begin{tabular}{|l|c|c|c|c|c|c|}
\hline Turistični kraj & $\begin{array}{c}\text { Število } \\
\text { prenočitev } \\
\text { (2002) }\end{array}$ & $\begin{array}{c}\text { Število } \\
\text { prenočitev/ } \\
\text { dan: število } \\
\text { stalnih preb. } \\
(2002)\end{array}$ & $\begin{array}{c}\text { Število } \\
\text { turističnih } \\
\text { ležišč (2004) }\end{array}$ & $\begin{array}{c}\text { Število } \\
\text { prenočitev } \\
\text { (2004) }\end{array}$ & $\begin{array}{c}\text { Śtevilo } \\
\text { prenočitev/ } \\
\text { dan/km² } \\
\text { (za občino; } \\
2004)\end{array}$ & $\begin{array}{c}\% \text { obiska } \\
\text { v obdobju } \\
\text { junij- } \\
\text { september } \\
(2004)\end{array}$ \\
\hline Bovec & 96.615 & 0,16 & 1400 & 107.686 & 1,00 & 66,5 \\
\hline Gozd Martuljek & 46.185 & 0,20 & 1066 & 43.074 & 4,36 & 63,9 \\
\hline Kranjska Gora & 318.711 & 0,61 & 2994 & 334.604 & 4,36 & 40,5 \\
\hline Podkoren & 1589 & 0,01 & 30 & 1775 & 4,36 & 29,7 \\
\hline Jezersko* & 10.818 & 0,05 & 221 & 9158 & 0,36 & 62,1 \\
\hline
\end{tabular}

* Vključeni so podatki za Zgornje in Spodnje Jezersko.

Vir/source: Podatki Statističnega urada Republike Slovenije in lastni izračuni.

Med izbranimi kraji ima Kranjska Gora daleč največje število letnih prenočitev in turističnih ležišč (preglednica 1). Tudi če ovrednotimo relativni pomen turizma na ta način, da primerjamo število prebivalcev in prenočitev vidimo, da je pomen turizma v Kranjski Gori največji. Na drugi strani je Jezersko, kjerještevilo prenočitev najmanjše. Tudi če ga primerjamo s številom prebivalcev ali površino občine so vrednosti ustreznih kazalcev najmanjše. Le pri številu prenočitev na prebivalca zaostaja Podkoren. Podatki o letni razporeditvi prenočitev 
pokažejo, da v treh krajih (Bovec, Jezersko, Gozd Martuljek) izrazito prevladuje poletna sezona, pri Kranjski Gori in Podkorenu pa je velikega pomena zimska sezona.

\section{I. Metodologija anketiranja}

Kot omenjeno, smo anketiranje izvedli v petih izbranih naseljih, ki naj bi bila dovolj reprezentativna za slovenski alpski svet v celoti. V drugi fazi smo s seznamov v telefonskem imeniku slučajno izbrali (s pomočjo programa SPSS) ustrezno število telefonskih naročnikov, ki so bili vključeni v vzorec. Vzorec je bil stratificiran glede na 'pripadnost' ustreznemu naselju oziroma glede na kraj bivanja, saj smo domnevali, da bodo ravno zelo velike razlike v stopnji turističnega razvoja in v značilnostih turizma igrale najpomembnejšo vlogo pri različnem opredeljevanju anketirancev do trditev, ki se nanašajo na možne pozitivne in negativne učinke turizma.

Število enot v posameznem stratumu bi lahko določili v skladu z deležem prebivalstva v določenem naselju glede na skupno število prebivalcev vseh upoštevanih naselij. Obravnavana naselja pa so zelo različno velika, zato bi morala biti v tako oblikovanem vzorcu velika večina anket opravljena v obeh največjih naseljih, t.j. Bovcu in Kranjski Gori. Ker pa smo želeli dobiti tudi vsaj grobo predstavo o odnosu domačinov do turizma po posameznih naseljih in s pomočjo ankete tudi identificirati nekatere glavne učinke turizma (kakor jih vidijo domačini), smo za manjša naselja predvideli večje število anket, kot bi jim pripadlo pri enostavni proporcionalni razmestitvi enot po stratumih. Iz tega razloga smo morali potem pri skupni obdelavi rezultatov ankete iz posameznih naselij ustrezno obtežiti. V preglednicah, predstavljenih v naslednjih podpoglavjih, so tako navedene obtežene vrednosti oziroma deleži, ki smo jih dobili na njihovi osnovi.

Anketiranje je bilo izvedeno po pošti, zato smo pričakovali precejšen delež neodgovorov. Zaradi tega smo po dveh do treh tednih poklicali prejemnike anket in preverili, če so poslali odgovor. Če tega niso storili, smo jih ponovno še po telefonu zaprosili za sodelovanje. Kljub večkratnim poskusom nekaterih prejemnikov anket nismo uspeli dobiti na telefon, precej pa jih je tudi po telefonski prošnji zavrnilo sodelovanje. Anketiranje je bilo tako časovno precej zamudno in je potekalo v obdobju od novembra 2002 do marca 2003. Na koncu smo dobili vrnjenih in izpolnjenih le okrog polovico odposlanih vprašalnikov (235 od 435), kar pa je glede na način anketiranja dokaj zadovoljiv delež. Seveda pa se je treba zavedati možnega vpliva razmeroma velikega števila neodgovorov na dobljene rezultate.

Preglednica 2: Število opravljenih anket (podatki po naseljih)

Table 2: Number of received questionnaires (data for settlements)

\begin{tabular}{|l|c|}
\hline Naselje & Število anket \\
\hline Bovec & 65 \\
\hline Gozd Martuljek & 43 \\
\hline Kranjska Gora & 54 \\
\hline Podkoren & 34 \\
\hline Zgornje Jezersko & 39 \\
\hline Skupaj & 235 \\
\hline
\end{tabular}


Primerjava lastnosti vzorca in celotnega prebivalstva izbranih naselij je pokazala ustrezno spolno strukturo vzorca ter preveliko zastopanost bolj izobraženih, kar smo sicer pričakovali. Pripravljenost za sodelovanje pri anketiranju je namreč pri nižje izobraženih v splošnem manjša, zato prihaja do premajhne zastopanosti nižje izobraženega prebivalstva (Vehovar 1991).

\subsection{Mnenje prebivalcev turističnih krajev v slovenskem alpskem svetu o učinkih turizma}

Osrednji del anketnega vprašalnika so sestavljali trije vsebinski sklopi. Prvi izmed njih se je osredotočil na pozitivne vplive turizma. V njem navedene trditve so se nanašale na gospodarske učinke, pozitivne vplive na okolje in izboljšano kakovost življenja.

Rezultati anketiranja so nedvoumno pokazali, da domačini opažajo številne pozitivne učinke turizma, saj se z vsemi trditvami o pozitivnih učinkih turizma strinja (popolnoma ali deloma) večina prebivalcev (preglednica 3).

Preglednica 3: Mnenje anketirancev o trditvah, ki se nanašajo na pozitivne učinke turizma (deleži v \%) Table 3: Opinions of respondents about statements regarding positive tourism impacts (share in \%)

\begin{tabular}{|l|c|c|c|c|c|}
\hline Trditev & $\begin{array}{c}\text { Se } \\
\text { popolnoma } \\
\text { strinjam }\end{array}$ & $\begin{array}{c}\text { Se deloma } \\
\text { strinjam }\end{array}$ & $\begin{array}{c}\text { Ne morem } \\
\text { se odločiti }\end{array}$ & $\begin{array}{c}\text { V glavnem } \\
\text { se ne } \\
\text { strinjam }\end{array}$ & $\begin{array}{c}\text { Sploh se ne } \\
\text { strinjam }\end{array}$ \\
\hline Boljša kakovost storitev & 17,6 & 44,2 & 4,0 & 19,7 & 14,6 \\
\hline Večja izbira glede trgovin & 25,6 & 30,6 & 2,0 & 23,6 & 18,2 \\
\hline $\begin{array}{l}\text { Boljše možnosti za } \\
\text { preživljanje prostega časa }\end{array}$ & 22,7 & 37,6 & 3,4 & 21,2 & 15,1 \\
\hline $\begin{array}{l}\text { Turizem prinaša našemu kraju } \\
\text { pomembne gospodarske koristi }\end{array}$ & 33,4 & 41,3 & 2,6 & 13,1 & 9,7 \\
\hline $\begin{array}{l}\text { Zaradi turizma je lažje najti } \\
\text { zaposlitev }\end{array}$ & 23,4 & 32,1 & 6,7 & 17,8 & 20,1 \\
\hline $\begin{array}{l}\text { Zaradi turizma se je povečala } \\
\text { skrb za okolje }\end{array}$ & 35,2 & 42,5 & 5,4 & 10,5 & 6,3 \\
\hline $\begin{array}{l}\text { Zaradi turizma je življenje v na- } \\
\text { šm kraju postalo bolj zanimivo }\end{array}$ & 26,9 & 40,9 & 3,2 & 17,5 & 11,5 \\
\hline $\begin{array}{l}\text { Domačini so postali bolj ponosni } \\
\text { na domači kraj }\end{array}$ & 28,8 & 30,4 & 10,5 & 13,5 & 16,8 \\
\hline $\begin{array}{l}\text { Povečala se je skrb za urejenost } \\
\text { naselja }\end{array}$ & 37,5 & 42,2 & 3,7 & 9,6 & 7,0 \\
\hline $\begin{array}{l}\text { Življenje v našem kraju se je } \\
\text { izboljšalo }\end{array}$ & 14,5 & 37,0 & 10,1 & 22,9 & 15,5 \\
\hline
\end{tabular}

Največja stopnja soglasja je bila pri trditvah, da se je zaradi turizma povečala skrb za urejenost naselja (skupni izračunani delež odgovorov 'se popolnoma strinjam' in 'se deloma strinjam' je 79,9 \%) ter da se je zaradi turizma povečala skrb za okolje $(77,7 \%$ \%). Obe trditvi govorita o tistih vrstah učinkov, ki so posledica prizadevanj domačega prebivalstva za večjo 
privlačnost turističnega območja, njihovi rezultati pa so pozitivni tako z vidika domačinov kot turistov.

Na tretjem mestu po stopnji soglasja anketirancev je trditev, da turizem kraju prinaša pomembne gospodarske koristi. Ker so prizadevanja za razvoj turizma prvenstveno povezana s pridobivanjem gospodarskih koristi, takšen rezultat pomeni, da so domačini prepričani o tem, da turizem to svojo nalogo dokaj dobro izpolnjuje.

Preglednica 4: Mnenje anketirancev o trditvah, ki se nanašajo na negativne učinke turizma (deleži v \%)

Table 4: Opinions of respondents about statements regarding negative tourism impacts (share in \%)

\begin{tabular}{|l|c|c|c|c|c|}
\hline Trditev & $\begin{array}{c}\text { Se } \\
\text { popolnoma } \\
\text { strinjam }\end{array}$ & $\begin{array}{c}\text { Se deloma } \\
\text { strinjam }\end{array}$ & $\begin{array}{c}\text { Ne morem } \\
\text { se odločiti }\end{array}$ & $\begin{array}{c}\text { V glavnem } \\
\text { se ne } \\
\text { strinjam }\end{array}$ & $\begin{array}{c}\text { Sploh se ne } \\
\text { strinjam }\end{array}$ \\
\hline $\begin{array}{l}\text { Mnogi turizmu namenjeni objekti } \\
\text { kvarijo videz kraja }\end{array}$ & 25,4 & 21,9 & 6,9 & 24,7 & 21,1 \\
\hline $\begin{array}{l}\text { Turizem povzroča v naselju } \\
\text { moteč hrup }\end{array}$ & 16,4 & 29,6 & 5,7 & 26,6 & 21,8 \\
\hline Daljše vrste v trgovinah & 32,2 & 27,5 & 5,3 & 24,2 & 10,8 \\
\hline $\begin{array}{l}\text { Zaradi turistov je velika } \\
\text { prometna gneča }\end{array}$ & 44,2 & 22,9 & 2,3 & 17,1 & 13,5 \\
\hline $\begin{array}{l}\text { Življenje v kraju je postalo } \\
\text { manj varno }\end{array}$ & 13,9 & 25,6 & 7,7 & 26,9 & 25,8 \\
\hline $\begin{array}{l}\text { Turizem je vplival na povečanje } \\
\text { življenjskih stroškov }\end{array}$ & 60,1 & 17,0 & 4,0 & 13,3 & 5,6 \\
\hline $\begin{array}{l}\text { Razvoj turizma koristi le } \\
\text { majhnemu delu prebivalcev }\end{array}$ & 52,5 & 24,7 & 2,9 & 14,8 & 5,1 \\
\hline $\begin{array}{l}\text { Turizem je povzročil škodo } \\
\text { naravnemu okolju }\end{array}$ & 21,1 & 28,2 & 3,6 & 27,9 & 19,2 \\
\hline $\begin{array}{l}\text { Zaradi turizma je na ulicah več } \\
\text { smeti in odpadkov }\end{array}$ & 31,5 & 26,2 & 2,1 & 24,8 & 15,3 \\
\hline $\begin{array}{l}\text { Zaradi turizma je v kraju več } \\
\text { socialnih problemov }\end{array}$ & 4,6 & 15,6 & 16,6 & 25,6 & 37,6 \\
\hline $\begin{array}{l}\text { Zaradi turizma so se povečale } \\
\text { socialne razlike med domačini }\end{array}$ & 21,3 & 25,5 & 11,0 & 25,2 & 17,0 \\
\hline $\begin{array}{l}\text { Zaradi turizma so se povečale } \\
\text { cene stanovanj in zemljišč }\end{array}$ & 56,2 & 21,9 & 8,5 & 9,6 & 3,7 \\
\hline $\begin{array}{l}\text { Prihaja do pogostih konfliktov } \\
\text { med turisti in domačini }\end{array}$ & 3,1 & 10,9 & 13,2 & 34,7 & 38,0 \\
\hline Turisti motijo naš način življenja & 6,3 & 18,4 & 5,2 & 35,6 & 34,6 \\
\hline $\begin{array}{l}\text { Turizem je prispeval k } \\
\text { spremembam in opušcanju } \\
\text { krajevnih običajev }\end{array}$ & 6,7 & 13,7 & 10,7 & 30,4 & 38,4 \\
\hline Turisti povzročajo škodo kmetom & 12,2 & 18,9 & 7,4 & 33,3 & 28,2 \\
\hline
\end{tabular}


Izrazita večina tudi soglaša s tem, da je zaradi turizma življenje postalo bolj zanimivo. Pri tem gre za manj 'otipljivo', a zato nič manj pomembno posledico turizma, rezultat pa priča o tem, da turizem na nekaterih področjih pomembno prispeva $\mathrm{k}$ izboljšani kvaliteti bivanja. Temu v prid govori tudi večinsko soglasje o tem, da se je zaradi turizma izboljšala kakovost storitev in da so se izboljšale možnosti za preživljanje prostega časa.

Tudi z ostalimi trditvami iz te skupine ('domačini so postali bolj ponosni na domači kraj', 'zaradi turizma je večja izbira glede trgovin', 'zaradi turizma je lažje najti zaposlitev') soglaša večina anketirancev, čeprav je stopnja soglasja z njimi manjša. Razmeroma skromno pa je strinjanje s trditvijo, da se je življenje v kraju izboljšalo. Analiza odgovorov po naseljih pokaže, da je to predvsem posledica razmeroma skromne intenzivnosti učinkov turizma in ne toliko velikega pomena negativnih učinkov.

Pri trditvah, ki označujejo različne negativne učinke turizma, v splošnem opazimo precej manjšo stopnjo soglasja. Le z manjšim delom trditev se strinja več kot polovica anketirancev. Tako velika večina prebivalcev ocenjuje, da je turizem vplival na povečanje cen stanovanj in zemljišč $(78,1 \%$ se jih s tem popolnoma ali deloma strinja) ter na povečanje življenjskih stroškov $(77,1 \%)$. Zelo visoka stopnja soglasja je tudi glede trditve, da razvoj turizma koristi le majhnemu delu prebivalcev $(77,1 \%)$. Posledica turizma so po mnenju domačinov tudi številne vsakdanje nevšečnosti, npr. velika prometna gneča $(67,1 \%)$ in daljše vrste $v$ trgovinah $(59,7 \%)$, poleg tega pa je na ulicah več smeti in odpadkov $(57,7 \%)$.

Z vsemi ostalimi trditvami soglaša manj kot polovica anketirancev. Zlasti majhen delež soglasja je bil pri trditvah, da turisti motijo način življenja domačinov $(24,7 \%)$, da je turizem prispeval k spremembam in opuščanju krajevnih običajev (20,4\%) in da je zaradi turizma več socialnih problemov. Na zadnjem mestu je bila trditev, da prihaja do pogostih konfliktov med turisti in domačini (14,0 \%). Potemtakem domačini v turizmu ne vidijo vplivnega dejavnika, ki bi ogrožal njihovo kulturo in način življenja, ali s katerim bi bili povezani konflikti med turisti in domačini.

Pregled mnenj anketirancev o trditvah, ki se nanašajo na pozitivne in negativne učinke turizma, je pokazal, da domačini opažajo oboje, vendar pa prevladuje pozitivno vrednotenje. To nam pokaže tudi mnenje domačinov o tem, ali je življenje v kraju zaradi turizma boljše ali slabše. Kar 52,0 \% jih meni, da je življenje zaradi turizma boljše, le 6,6 \% pa, da je življenje zaradi njega slabše. Zelo velik je tudi delež tistih, ki menijo, da turizem nima pomembnejšega vpliva na boljše ali slabše življenje v njihovem kraju.

Preglednica 5: Mnenje anketirancev o pomenu vplivov turizma na kakovost življenja v njihovem kraju Table 5: Opinions of respondents regarding influence of tourism on quality of living in their settlement (share in \%)

\begin{tabular}{|l|c|}
\hline $\begin{array}{l}\text { Ali menite, da je življenje v vašem kraju } \\
\text { zaradi turizma }\end{array}$ & $\begin{array}{c}\text { Delež odgovorov } \\
\text { v \% }\end{array}$ \\
\hline Boljše & 52,0 \\
\hline Slabše & 6,6 \\
\hline Turizem nima pomembnejšega vpliva & 41,3 \\
\hline Skupaj & 100,0 \\
\hline
\end{tabular}


Od tega, kako domačini zaznavajo pozitivne in negativne učinke turizma oziroma kako vrednotijo dosedanje vplive turizma, je odvisna tudi njihova podpora nadaljnjemu razvoju turizma. Tako se prevladujoče pozitivno vrednotenje dosedanjih učinkov razvoja turizma pokaže tudi v zelo majhnem deležu (3,1 \%) tistih, ki se ne strinjajo s trditvijo, da bi nadaljnji razvoj turizma koristil kraju. Zelo podoben rezultat nam dajo mnenja o vsebinsko nasprotni trditvi, da nadaljnjega razvoja turizma ne bi smeli več spodbujati. Kar 81 \% anketirancev se namreč v glavnem ne strinja ali sploh ne strinja s to trditvijo. To nazorno priča o prevladujoče pozitivnem odnosu domačinov do turizma.

Preglednica 6: Mnenje anketirancev o trditvah o razvoju turizma v prihodnje (delež veljavnih odgovorov $v \%)$

Table 6: Opinions of respondents about future tourism development (share of valid responses in \%)

\begin{tabular}{|l|c|c|c|c|c|}
\hline Trditev & $\begin{array}{c}\text { Se } \\
\text { popolnoma } \\
\text { strinjam }\end{array}$ & $\begin{array}{c}\text { Se deloma } \\
\text { strinjam }\end{array}$ & $\begin{array}{c}\text { Ne morem } \\
\text { se odločiti }\end{array}$ & $\begin{array}{c}\text { V glavnem } \\
\text { se ne } \\
\text { strinjam }\end{array}$ & $\begin{array}{c}\text { Sploh se ne } \\
\text { strinjam }\end{array}$ \\
\hline $\begin{array}{l}\text { Nadaljnji razvoj turizma } \\
\text { bi koristil kraju }\end{array}$ & 72,9 & 20,6 & 3,4 & 2,0 & 1,1 \\
\hline $\begin{array}{l}\text { Število turistov bi se moralo } \\
\text { še povečati }\end{array}$ & 58,4 & 23,4 & 3,7 & 8,1 & 6,4 \\
\hline $\begin{array}{l}\text { Zgraditi bi bilo treba nove } \\
\text { hotele ali druge vrste prenočišč }\end{array}$ & 21,3 & 21,3 & 8,4 & 24,1 & 25,0 \\
\hline $\begin{array}{l}\text { Povečati bi bilo treba število } \\
\text { objektov in površin, namenjenih } \\
\text { rekreaciji in športu }\end{array}$ & 74,0 & 16,7 & 2,5 & 2,2 & 4,6 \\
\hline $\begin{array}{l}\text { Izboljšati bi bilo treba prometno } \\
\text { infrastrukturo }\end{array}$ & 77,7 & 13,9 & 2,6 & 4,0 & 1,8 \\
\hline $\begin{array}{l}\text { Nadaljnjega razvoja turizma } \\
\text { ne bi smeli več spodbujati }\end{array}$ & 5,3 & 6,4 & 7,3 & 18,7 & 62,3 \\
\hline
\end{tabular}

Zelo zanimiv je tudi delež domačinov, ki se (popolnoma ali deloma) strinjajo s trditvijo, da bi se število turistov moralo še povečati. Ta delež znaša kar 81,8 \%. Mogoče ta rezultat še najbolje od vseh opozarja na to, da so domačini v veliki meri pripravljeni sprejeti celo razmeroma negativne učinke, povezane s turizmom in turisti, ki se jih dobro zavedajo in jih tudi precej motijo. Vendar pa v splošnem ocenjujejo, da imajo od turizma več koristi (materialnih in drugih) kot škode in da potemtakem razvoj turizma koristi kraju - kljub temu, da morajo biti posamezniki zaradi njega soočeni tudi z vrsto negativnih posledic.

\subsection{Primerjava mnenj anketirancev iz različnih naselij o učinkih turizma}

Pri mnenju anketirancev o turizmu in njegovih pozitivnih vplivih so že na prvi pogled opazna velika razhajanja med odgovori anketirancev iz posameznih naselij. Tako so anketiranci iz vseh treh naselij v Zgornjesavski dolini, ki predstavlja dovolj razvito turistično območje, v precej večji meri kot v ostalih dveh naseljih menili, da je bila posledica turizma tudi večja skrb za njihovo okolico, pa naj gre za domači kraj ali pa naravno okolje. Z obema trditvama je soglašalo največ anketirancev iz Podkorena (87,5 in 93,8 \%), najmanj pa iz 
Bovca (67,7 in 61,5 \%). Podobno situacijo najdemo tudi pri trditvi o gospodarskih koristih kot posledici turizma. Z njo se je strinjalo največ anketirancev iz Kranjske Gore (87,0 \%), kar je glede na dejansko razvitost turizma pričakovan rezultat. Na drugem mestu je Podkoren, ki v veliki meri predstavlja funkcijsko celoto skupaj s Kranjsko Goro, čeprav gre pri tem predvsem za odvisnost Podkorena od Kranjske Gore (na področju oskrbe, storitev), na tretjem pa Gozd Martuljek. Na Jezerskem in v Bovcu sta bili takšnega mnenja približno dve tretjini anketirancev.

$\mathrm{V}$ splošnem se anketiranci s pozitivnimi trditvami v najmanjši meri strinjajo v Bovcu, kjer $\mathrm{z}$ nobeno izmed $\mathrm{v}$ anketi navedenih trditev ni soglašalo niti $70 \%$ anketirancev. Za primerjavo naj izpostavimo dejstvo, da se je v Kranjski Gori samo z eno trditvijo strinjal manjši delež anketirancev. Zaznavanje pozitivnih učinkov turizma v teh dveh krajih torej v okviru naših izbranih primerov predstavlja dve skrajnosti.

Čeprav anketiranci zelo cenijo gospodarske koristi, ki jih prinaša turizem, pa kaže opozoriti na dejstvo, da pozitivne učinke na področju zaposlovanja opažajo v precej manjši meri. V povprečju je manjše soglasje samo še s trditvijo, da se je zaradi turizma življenje v kraju izboljšalo. Značilno pa je, da v obeh primerih tovrstne pozitivne učinke v največji meri opažajo anketiranci v Zgornjesavski dolini, kjer je turizem tudi najbolj razvit. Na osnovi tega bi lahko sklepali, da turistični razvoj ni dosegel tolikšnega obsega, da bi njegovi stranski učinki vzbujali nezadovoljstvo med širšimi krogi prebivalcev, ampak ravno zaradi večje razvitosti turizma domačini bolj opažajo njegove pozitivne vplive.

Preglednica 7: Deleži anketirancev, ki popolnoma ali deloma soglašajo z izbranimi trditvami o pozitivnih učinkih turističnega razvoja

Table 7: Percentages of respondents who completely or partly agree with the statements regarding positive tourism impacts

\begin{tabular}{|l|c|c|c|c|c|}
\hline & Jezersko & $\begin{array}{c}\text { Gozd } \\
\text { Martuljek }\end{array}$ & Podkoren & $\begin{array}{c}\text { Kranjska } \\
\text { Gora }\end{array}$ & Bovec \\
\hline Boljša kakovost storitev & 56,4 & 65,1 & 71,9 & 85,2 & 40,0 \\
\hline Večja izbira glede trgovin & 46,2 & 53,5 & 78,8 & 79,6 & 35,4 \\
\hline $\begin{array}{l}\text { Boljše možnosti za preživljanje } \\
\text { prostega časa }\end{array}$ & 44,8 & 62,8 & 74,2 & 80,7 & 44,6 \\
\hline $\begin{array}{l}\text { Turizem prinaša našemu kraju } \\
\text { pomembne gospodarske koristi }\end{array}$ & 66,7 & 76,2 & 81,3 & 87,0 & 64,6 \\
\hline Zaradi turizma je lažje najti zaposlitev & 47,4 & 61,9 & 71,9 & 66,1 & 43,1 \\
\hline $\begin{array}{l}\text { Zaradi turizma se je povečala skrb } \\
\text { za okolje }\end{array}$ & 76,3 & 83,8 & 87,5 & 84,9 & 67,7 \\
\hline $\begin{array}{l}\text { Zaradi turizma je življenje v našem } \\
\text { kraju postalo bolj zanimivo }\end{array}$ & 58,9 & 62,8 & 65,6 & 77,7 & 64,6 \\
\hline $\begin{array}{l}\text { Domačini so postali bolj ponosni } \\
\text { na domači kraj }\end{array}$ & 50,0 & 66,7 & 57,6 & 71,7 & 49,3 \\
\hline Povečala se je skrb za urejenost naselja & 84,7 & 90,7 & 93,8 & 90,5 & 61,5 \\
\hline Življenje v našem kraju se je izboljšalo & 39,4 & 53,5 & 48,5 & 75,4 & 35,4 \\
\hline
\end{tabular}


Mnenja anketirancev iz različnih naselij se precej razlikujejo tudi v zvezi z negativnimi učinki turizma. Kot že omenjeno, je bilo največje soglasje o trditvi, da so se zaradi turizma povečale cene stanovanj in zemljišč, vendar so bili glede tega izjema anketiranci iz Zgornjega Jezerskega, kjer se je z omenjeno trditvijo strinjalo le 44,7 \% anketirancev. Pričakovati je mogoče, da je takšno mnenje anketirancev posledica lokalnih razmer. Za razliko od večine ostalih naselij je namreč na Jezerskem turizem dokaj skromno razvit in tudi število počitniških stanovanj ni zelo veliko (2002: 39), zato porast cen stanovanj in zemljišč ni bil tolikšen kot npr. na območju Kranjske Gore. V nasprotju s tem so bili deleži anketirancev, ki so se v celoti ali deloma strinjali z navedeno trditvijo, v ostalih naseljih med 70 in $95 \%$ (Bovec 72,3 \%, Gozd Martuljek 85,0 \%, Kranjska Gora 90,7 \%, Podkoren 93,9 \%). Najvišja deleža sta bila torej zabeležena $v$ obeh naseljih, ki sta zaradi turističnega razvoja v Kranjski Gori deležni največjih učinkov tega razvoja (tudi na področju sprememb cen nepremičnin).

Manjše so bile razlike med naselji pri trditvi, da razvoj turizma koristi le majhnemu delu prebivalcev. Še najmanjši je bil delež anketirancev, ki so se s tem strinjali, v Kranjski Gori (66,7 \%). V ostalih naseljih so bili deleži nad $70 \%$ (Podkoren 71,9 \%, Gozd Martuljek 76,2 \%, Bovec 84,4 \%, Jezersko 87,2 \%). Razlog za to gre iskati v dejstvu, na katerega smo opozarjali že na drugem mestu, da je turizem najbolj razvit v Kranjski Gori, zato je tudi njegovih koristi tam deležno največ prebivalcev. Potemtakem s tem povezana mnenja ne opozarjajo le na morebitno neenakomerno porazdelitev koristi od turizma ali povečevanje socialnih razlik, temveč ravno tako tudi na stopnjo turističnega razvoja, ki vpliva na distribucijo koristi. Pri večji razvitosti turizma so koristi deležni širši sloji prebivalcev, očitno pa se hkrati povečujejo tudi socialne razlike med njimi. Da so se zaradi turizma povečale socialne razlike med domačini, je sicer v štirih od petih naselij menila le manjšina anketirancev, v naselju z najbolj razvitim turizmom (v Kranjski Gori) pa je prepričljiva večina (71,7 \%) anketirancev soglašala s to trditvijo

Tudi s trditvijo, da je turizem vplival na povečanje življenjskih stroškov, se strinja veli-ka večina anketirancev iz obravnavanih naselij, z izrazito izjemo Jezerskega. Če se je z omenjeno trditvijo v treh krajih strinjalo celo več kot $80 \%$ anketirancev (Kranjska Gora 81,5\%, Podkoren 81,8 \%, Bovec 89,2 \%), je bil na Jezerskem ustrezni delež le 33,3 \%! Verjetno na takšen rezultat vpliva dejstvo, da je bilo območje Jezerskega izmed vseh obravnavanih primerov deležno še najmanjših sprememb zaradi turizma.

Jezersko je bilo izjema tudi pri trditvi, da je zaradi turistov velika prometna gneča. Le 36,8 $\%$ anketirancev z Zgornjega Jezerskega je s tem soglašalo, medtem ko so bili ustrezni deleži v ostalih štirih naseljih povsod krepko večji od $60 \%$ ali celo 70 \% (Gozd Martuljek 65,1 \%, Bovec 69,2 \%, Podkoren 71,9 \%, Kranjska Gora 75,9 \%). Del razloga za takšen rezultat je mogoče najti $v$ dejstvu, da so prebivalci vseh štirih krajev soočeni z večjim turističnim obiskom, prebivalci Gozda Martuljka, Kranjske Gore in Podkorena pa so deležni tudi precej bolj obsežnega tranzitnega prometa. Tudi primerajava podatkov o povprečnem dnevnem prometu govori temu v prid (Cigale 2004).

Pri trditvi, da so zaradi turistov daljše vrste v trgovinah, Jezersko ponovno izstopa, saj je takšnega mnenja le 36,8 \% tamkajšnjih anketirancev, drugod pa je s to trditvijo soglašala več kot polovica (Gozd Martuljek 51,2 \%, Kranjska Gora 57,4 \%, Podkoren 67,7 \%, Bovec 70,8 \%). Pri interpretaciji teh odgovorov bi bilo treba upoštevati številčno razmerje med domačini in 
turisti, sezonski potek in koncentracijo turističnega obiska ter značilnosti trgovske ponudbe, pa tudi to, da veliko prebivalcev zadovoljuje svoje potrebe po trgovskih storitvah v kraju zaposlitve.

Preglednica 8: Deleži anketirancev, ki popolnoma ali deloma soglašajo z izbranimi trditvami o negativnih učinkih turističnega razvoja

Table 8: Percentages of respondents who completely or partly agree with the statements regarding negative tourism impacts

\begin{tabular}{|l|c|c|c|c|c|}
\hline & Jezersko & $\begin{array}{c}\text { Gozd } \\
\text { Martuljek }\end{array}$ & Podkoren & $\begin{array}{c}\text { Kranjska } \\
\text { Gora }\end{array}$ & Bovec \\
\hline $\begin{array}{l}\text { Mnogi turizmu namenjeni objekti } \\
\text { kvarijo videz kraja }\end{array}$ & 63,1 & 37,2 & 48,4 & 57,4 & 37,0 \\
\hline Turizem povzroča v naselju moteč hrup & 47,3 & 44,2 & 58,1 & 55,6 & 35,4 \\
\hline Daljše vrste v trgovinah & 36,9 & 51,2 & 67,7 & 57,4 & 70,8 \\
\hline Zaradi turistov je velika prometna gneča & 36,9 & 65,2 & 71,9 & 76,0 & 69,2 \\
\hline Življenje v kraju je postalo manj varno & 31,6 & 39,5 & 43,8 & 50,0 & 32,3 \\
\hline $\begin{array}{l}\text { Turizem je vplival na povečanje } \\
\text { življenjskih stroškov }\end{array}$ & 33,3 & 72,1 & 81,8 & 81,5 & 89,2 \\
\hline $\begin{array}{l}\text { Razvoj turizma koristi le majhnemu } \\
\text { delu prebivalcev }\end{array}$ & 87,2 & 76,2 & 71,9 & 66,7 & 84,4 \\
\hline $\begin{array}{l}\text { Turizem je povzročil škodo naravnemu } \\
\text { okolju }\end{array}$ & 53,9 & 54,8 & 59,4 & 48,2 & 44,6 \\
\hline $\begin{array}{l}\text { Zaradi turizma je na ulicah več smeti } \\
\text { in odpadkov }\end{array}$ & 59,0 & 50,0 & 59,4 & 52,8 & 64,1 \\
\hline $\begin{array}{l}\text { Zaradi turizma je v kraju več socialnih } \\
\text { problemov }\end{array}$ & 10,3 & 16,7 & 16,1 & 33,3 & 14,3 \\
\hline $\begin{array}{l}\text { Zaradi turizma so se povečale socialne } \\
\text { razlike med domačini }\end{array}$ & 20,5 & 39,1 & 46,9 & 71,7 & 37,5 \\
\hline $\begin{array}{l}\text { Zaradi turizma so se povečale cene } \\
\text { stanovanj in zemljǐč }\end{array}$ & 44,8 & 85,0 & 93,9 & 90,7 & 72,3 \\
\hline $\begin{array}{l}\text { Prihaja do pogostih konfliktov med } \\
\text { turisti in domačini }\end{array}$ & 13,5 & 15,0 & 18,8 & 9,3 & 16,9 \\
\hline Turisti motijo naš način življenja & 26,3 & 22,5 & 34,4 & 26,0 & 21,6 \\
\hline $\begin{array}{l}\text { Turizem je prispeval k spremembam in } \\
\text { opuščanju krajevnih običajev }\end{array}$ & 10,5 & 17,5 & 28,1 & 24,1 & 20,0 \\
\hline Turisti povzročajo škodo kmetom & 31,6 & 35,0 & 37,5 & 31,5 & 27,7 \\
\hline
\end{tabular}

V vseh krajih so med anketiranci mnenja zelo deljena glede trditve, da je turizem povzročil škodo naravnemu okolju. Deleži anketirancev, ki se s to trditvijo strinjajo, so med 40 in 60 \% (natančneje 44,6 do 59,4 \%). Takšne odgovore najbrž lahko pripišemo temu, da so negativni okoljski vplivi dostikrat (vsaj na prvi pogled) teže prepoznavni, pa tudi temu, da turizem večinoma povzroča takšne okoljske obremenitve, kakršne povzročajo tudi druge dejavnosti, zaradi česar je prepoznavanje njihove povezanosti s turizmom lahko pogojeno s posameznikovim vrednotenjem turizma kot celote, oziroma z njim povezanih stroškov in 
koristi. Ker so ponavadi koristi večje, se tudi pri vrednotenju tovrstnih vplivov posameznik težje opredeli za to, da bi okoljske obremenitve pripisal predvsem turizmu. Drug pomemben moment pa je, da turizem razmeroma redko povzroča zelo očitne okoljske vplive.

Soglasje z ostalimi trditvami o negativnih učinkih turizma je bilo v vseh krajih razmeroma skromno.

Odgovori na vprašanje, ali je življenje v kraju zaradi turizma boljše ali slabše, so pokazali na precejšnje razlike med naselji (slika 2). Tako je v Kranjski Gori kar 78,3 \% anketirancev menilo, da je zaradi turizma življenje v njihovem kraju boljše, v Podkorenu je ta delež še zmeraj večji od dveh tretjin $(67,7$ \%), v vseh ostalih naseljih pa je manjši od polovice (Gozd Martuljek 46,2 \%, Bovec 39,3 \%, Zgornje Jezersko 26,3 \%). Deleži anketirancev, ki so menili, da je zaradi turizma življenje v kraju slabše, so bili v vseh krajih (z izjemo Podkorena) manjši od $10 \%$. Razmeroma precej je tistih, ki so zatrjevali, da turizem nima pomembnejšega vpliva na življenje v njihovem kraju. Precejšen delež neodločenih pri posameznih trditvah je torej verjetno tudi posledica tega, da je vpliv turizma na življenje razmeroma skromen.

Slika 2: Mnenje anketirancev o vplivu turizma na kakovost življenja v turističnem kraju Figure 2: Opinions of respondents about impacts of tourism on quality of living in tourist resort

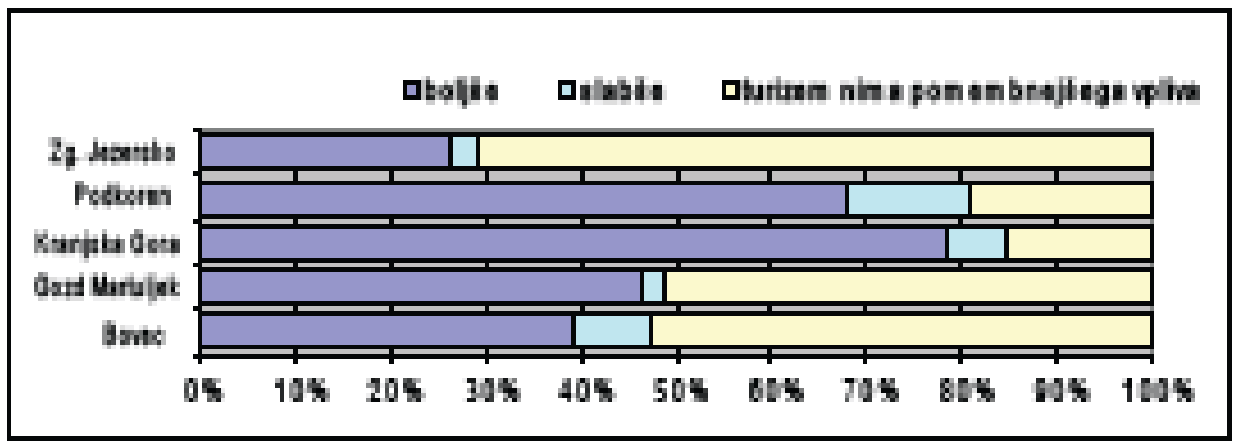

V zvezi s prihodnjim razvojem turizma so prebivalci obravnavanih naselij mnenja, da lahko njihov kraj od njega pričakuje koristi (preglednica 9). Tako je več kot $90 \%$ anketirancev iz vseh naselij - z izjemo Gozda Martuljka - menilo, da bi nadaljnji razvoj turizma koristil njihovemu kraju. Večje razlike se pokažejo, če upoštevamo mnenja o povečanju števila turistov ali nastanitvenih zmogljivosti.

Najmanjše soglasje s trditvijo, da naj bi se število turistov v kraju še povečalo, je v Podkorenu in Kranjski Gori (deloma ali v celoti je s tem soglašalo 57,5 oz. 76,4 \% anketirancev), torej v naseljih na turistično najbolj razvitem območju, največje pa v Bovcu in na Jezerskem - torej na območjih, ki sta turistično precej manj razviti kot območje Kranjske Gore. Precej zanimive ugotovitve dobimo, če si pobliže pogledamo mnenje anketirancev o nadaljnji gradnji hotelov in drugih vrst prenočišč. V večini naselij (v štirih od petih) je s to trditvijo soglašala le manjšina, na Jezerskem pa kar 84,2 \% anketirancev! Takšno razliko lahko pojasnimo predvsem z majhnim številom turističnih ležišč na območju Jezerskega. 
Preglednica 9: Mnenje anketirancev o prihodnjem razvoju turizma (delež veljavnih odgovorov v\%) Table 9: Opinions of respondents regarding future tourism development (\% of valid responses)

\begin{tabular}{|l|c|c|c|c|c|}
\hline & Jezersko & $\begin{array}{c}\text { Gozd } \\
\text { Martuljek }\end{array}$ & Podkoren & $\begin{array}{c}\text { Kranjska } \\
\text { Gora }\end{array}$ & Bovec \\
\hline Nadaljnji razvoj turizma bi koristil kraju & 97,4 & 84,8 & 97,5 & 90,2 & 95,3 \\
\hline Število turistov bi se moralo še povečati & 86,8 & 80,0 & 57,5 & 76,4 & 90,7 \\
\hline $\begin{array}{l}\text { Zgraditi bi bilo treba nove hotele } \\
\text { ali druge vrste prenočišc }\end{array}$ & 84,2 & 31,7 & 39,4 & 40,4 & 34,9 \\
\hline $\begin{array}{l}\text { Povečati bi bilo treba število objektov in } \\
\text { površin, namenjenih rekreaciji in športu }\end{array}$ & 92,1 & 92,7 & 87,1 & 92,3 & 88,9 \\
\hline $\begin{array}{l}\text { Izboljšati bi bilo treba prometno } \\
\text { infrastrukturo }\end{array}$ & 89,2 & 95,2 & 83,9 & 96,1 & 88,9 \\
\hline $\begin{array}{l}\text { Nadaljnjega razvoja turizma ne bi } \\
\text { smeli več spodbujati }\end{array}$ & 8,1 & 14,3 & 12,5 & 14,0 & 9,7 \\
\hline
\end{tabular}

Predstavljeni rezultati opozarjajo na kompleksen odnos prebivalstva turističnih območij v slovenskem alpskem svetu do turizma in njegovih učinkov. Percepcija pozitivnih ali negativnih učinkov turizma je odvisna od številnih značilnosti razvoja turizma. Med njimi kaže posebej omeniti stopnjo njegove razvitosti, ki pogojuje intenziteto z njim povezanih učinkov. Tako npr. v turistično najbolj razviti Kranjski Gori ni nadpovprečno velika samo stopnja soglasja s pozitivnimi trditvami, ampak so tudi negativni učinki nadpovprečno izraženi, zato se jih prebivalci Podkorena in Kranjske Gore bolj zavedajo, oziroma jih bolj opažajo kot prebivalci drugih krajev. Na drugi strani je soglasje prebivalcev Jezerskega z navedbami o pozitivnih učinkih turizma na Jezerskem nižje od povprečja, podobno pa velja tudi za trditve o negativnih učinkih turizma. Takšno stanje lahko pripišemo manjši razvitosti turizma. Primerjanje turistično različno razvitih krajev je zato nujno moralo dati precej različne rezultate.

\section{SKLEP}

Rezultati raziskave so pokazali, kateri pozitivni in negativni učinki turističnega razvoja so po mnenju domačinov pomembnejši. Kljub razlikam med kraji, v katerih je bilo izvedeno anketiranje, so bile ugotovljene številne skupne značilnosti. Pri tem gre za na splošno pozitiven odnos do turizma ter za dejstvo, da so kot najpomembnejši vrednoteni ekonomski, kot najmanj pomembni pa socio-kulturni učinki turizma.

Domačini povsod opažajo številne pozitivne učinke, med njimi pa so najbolj očitni tisti, ki so povezani s skrbjo za videz kraja in okolje, sledijo pa jim s turizmom povezane gospodarske koristi, vendar pri tem niso v ospredju boljše zaposlitvene možnosti. Večina opaža tudi pozitiven vpliv na kakovost življenja, ki se kaže v boljših možnostih za preživljanje prostega časa in boljši kakovosti storitev. Na drugi strani so poglavitni negativni družbeni učinki turizma tisti, ki sodijo v sklop ekonomskih učinkov. Domačini so tako prizadeti predvsem zaradi povečanih življenjskih stroškov, pa naj gre za cene stanovanj ali pa vsakodnevnih življenjskih potrebščin. Poleg tega so zanje moteče tudi različne vsakdanje nevšečnosti, ki so 
povezane predvsem s povečanim obiskom v času glavne turistične sezone (prometna gneča, hrup, vrste v trgovinah). Ostale negativne posledice so v splošnem nekoliko v ozadju. Ker pa domačini od turizma vendarle pričakujejo pomembne gospodarske koristi in čutijo, da so od njega v precejšnji meri odvisni, povrh tega pa na številnih področjih prispeva tudi $\mathrm{k}$ izboljšani kakovosti življenja (npr. boljše storitve, infrastruktura), so pripravljeni negativnim učinkom pripisati manjši pomen, zato turizem v celoti vrednotijo pozitivno. Velika vloga gospodarskega vidika pri vrednotenju turizma je pogojena tudi z manjšo vlogo drugih gospodarskih alternativ. Poleg tega so zaradi prometne oddaljenosti do večjih središč druge zaposlitvene priložnosti marsikje težje dosegljive.

Rezultati kažejo, da v splošnem domačini pripisujejo turizmu vpliv na boljše življenje v svojem kraju predvsem v tistih primerih, kjer je stopnja razvoja turizma tolikšna, da so njegovi pozitivni učinki dovolj opazni in razširjeni. Na drugi strani so tudi njegovi negativni učinki moteči predvsem v primeru njegove večje razvitosti, so pa bolj moteči, kadar imajo prebivalci občutek, da od njega nimajo pravih koristi.

O na splošno pozitivnem mnenju domačinov o turizmu in njegovih učinkih na območju slovenskega alpskega sveta govorijo tudi ugotovitve nekaterih drugih raziskav, npr. rezultati anketiranja v Bohinju (Maraž 2007), ali pa anketiranja, izvedenega v okviru terenskih vaj študentov geografije v letih 2005 in 2006 (Delovno gradivo 2005-2006). Potemtakem lahko zaključimo, da turizem v slovenskem alpskem svetu še ni dosegel tolikšne stopnje razvoja, da bi začel med domačini v večji meri sprožati negativne odzive.

Učinki turizma seveda niso povsod enaki, ampak so prisotne precejšnje razlike med območji. Intenziteta in značaj učinkov turizma sta odvisna od številnih dejavnikov, ki so specifični za določena območja, in ki potemtakem posredno vplivajo tudi na percepcijo domačinov. Povezani so tudi z značilnostmi turistične ponudbe in turistov ter s hitrostjo in intenziteto turističnega razvoja. Podobna raziskava, izvedena na območju z bolj intenzivnim turističnim razvojem, bi verjetno dala drugačne rezultate. Na to opozarjajo npr. ugotovitve za Piran (Tkalčič 2006), kjer je mnenje domačinov o učinkih turizma precej manj pozitivno.

Raziskava je opozorila na nekatere problematične vidike razvoja turizma v slovenskem alpskem svetu, na katere je treba biti pozoren. Prihodnja rast turizma, za katero se zavzemajo tudi domačini, bo postavljala dodatne zahteve obstoječi prometni in komunalni infrastrukturi, stopnjevala pa bo tudi pritiske na okolje. Brez ustreznega reševanja s tem povezane problematike se bo zmanjšala tudi podpora domačinov razvoju turizma.

\section{Viri in literatura}

Andereck, K. L., Valentine, K. M., Knopf, R. C., Vogt, C. A. 2005: Residents' perceptions of community tourism impacts. Annals of tourism research 32, 4. New York.

Andriotis, K. 2005: Community groups' perceptions of and preferences for tourism development: evidence from Crete. Journal of hospitality \& tourism research 29 . Washington.

Andriotis, K., Vaughan, R. D. 2003: Urban residents' attitudes toward tourism development: the case of Crete. Journal of travel research 42 (November 2003). Boulder.

Baysan, S. 2001: Perceptions of the environmental impacts of tourism: a comparative study of the attitudes of German, Russian and Turkish tourists in Kemer, Antalya. Tourism geographies 3 (2). London. 
Bestard, A. B., Nadal, J. R. 2007: Modelling environmental attitudes toward tourism. Tourism management 28, 3. Guildford.

Brunt, P., Courtney, P. 1999: Host perceptions of sociocultural impacts. Annals of tourism research 26, 3. New York.

Chen, J. S. 2001: Assessing and visualizing tourism impacts from urban residents' perspectives. Journal of hospitality \& tourism research 25, 3. Washington.

Cigale, D. 2004. Posledična navzkrižja in obremenitve slovenskega alpskega sveta zaradi turistične in rekreativne dejavnosti. Doktorska disertacija, Oddelek za geografijo, Filozofska fakulteta Univerze v Ljubljani. Ljubljana.

Coles, T., Shaw, G. 2003: Interakcija između lokalnih stanovnika i turista: pouke za održivo upravljanje turizmom iz Batha. Turizam 51, 2. Zagreb.

Delovno gradivo s terenskih vaj študentov geografije v letih 2005-2006. Oddelek za geografijo Filozofske fakultete Univerze v Ljubljani. Ljubljana.

Fredline, E., Faulkner, B. 2000: Host community reactions: a cluster analysis. Annals of tourism research 27, 3. New York.

Gezici, F. 2005: Components of sustainability: two cases from Turkey. Annals of tourism research 33, 2. New York.

Gilbert, D., Clark, M. 1997: An exploratory examination of urban tourism impact, with reference to residents attitudes, in the cities of Canterbury and Guildford. Cities 14, 6. Guildford.

Gunce, E. 2003: Tourism and local attitudes in Girne, Northern Cyprus. Cities 20, 3. Guildford.

Haralambopoulos, N., Pizam, A. 1996: Perceived impacts of tourism: the case of Samos. Annals of tourism research 23, 3. New York.

Jurowski, C., Gursoy, D. 2004: Distance effects on residents' attitudes toward tourism. Annals of tourism research 31, 2. New York.

Kariel, H. G., Kariel, P. E. 1982: Socio-cultural impacts of tourism: an example from the Austrian Alps. Geografiska annaler, series B 64. Stockholm.

Lawson, R. W., Williams, J., Young, T., Cossens, J. 1998: A comparison of residents' attitudes towards tourism in 10 New Zealand destinations. Tourism management 19, 3. Guildford.

Lee, C. K., Back, K. J. 2003: Pre- and post-Casino impact of residents' perception. Annals of tourism research 30, 4. New York.

Maraž, D. 2007: Poskus analize turistične nosilne zmogljivosti na primeru občine Bohinj. Diplomsko delo, Oddelek za geografijo, Filozofska fakulteta Univerze v Ljubljani. Ljubljana.

McGehee, N. G., Andereck, K. 2004: Factors predicting rural residents' support of tourism. Journal of travel research 43 (November 2004). Boulder.

Müller, H. R. 1986: Tourismus in Berggemeinden: Nutzen und Schaden. Schlussbericht zum schweizerischen MAB-Programm 19. Bern.

Padilla y Sotelo, L. S., Luna Moliner, A. M. 2003: Percepción y conocimiento ambiental en la costa de Quintana Roo: Una caracterización a través de encuestas. Investigaciones geográficas 52. Ciudad de México. 
Pavlin, B., Ilič, M., Žnidaršič, E., Milenković, A., Klasinc, S., Grm, B. 2004: Mestna naselja v Republiki Sloveniji. Ljubljana.

Perdue, R. R., Long, P. T., Kang, Y. S. 1999: Boomtown tourism and resident quality of life: the marketing of gaming to host community residents. Journal of business Research 44, 3. New York.

Ponce Sánchez, M. D. 2004a: La calidad ambiental como factor competitivo de los destinos tradicionales de sol y playa. Cuadernos de turismo 13. Murcia.

Ponce Sánchez, M. D. 2004b: Percepción del modelo turístico de sol y playa. El caso del Mar Menor. Papeles de geografía 39. Murcia.

Puczkó, L., Rátz, T. 2000: Tourism and resident perceptions of the physical impacts of tourism at Lake Balaton, Hungary: issues for sustainable tourism management. Journal of sustainable tourism 8,6 . Clevedon.

Rátz, T. 2002: The socio-cultural impacts of tourism. http://www.geocities.com/Paris/9842/ impacts.html (2.7.2002).

Razvojni načrt in usmeritve slovenskega turizma 2007-2011. Ministrstvo za gospodarstvo. Ljubljana 2007.

Ryan, C., Scotland, A., Montgomery, D. 1998: Resident attitudes to tourism development: a comparative study between the rangitikei, New Zealand and Bakewell, United Kingdom. Progress in tourism hospitality research 4 . Chichester.

Saveriades, A. 2000: Establishing the social tourism carrying capacity for the tourist resorts of the east coast of the Republic of Cyprus. Tourism management 21, 2. Guildford.

Snaith, T., Haley, A. 1999: Residents' opinions of tourism development in the historic city of York, England. Tourism management 20, 5. Guildford.

Tkalčič, D. 2006: Analiza mnenj Pirančanov o okoljskih vplivih turizma. Seminarska naloga v okviru podiplomskega študija turizma. Univerza na Primorskem. Portorož.

Tosun, C. 2002: Host perceptions of impacts: a comparative tourism study. Annals of tourism research 29, 1. New York.

Upchurch, R. S., Teivane, U. 2000: Resident perceptions of tourism development in Riga, Latvia. Tourism management 21, 5. Guildford.

Vehovar, V. 1991: Metodološka vprašanja vzorčenja. Ljubljana.

\section{ATTITUDE OF THE POPULATION OF SLOVENIAN ALPINE TOURIST RESORTS TOWARD TOURISM AND ITS IMPACTS}

\section{Summary}

The Alps are an important European tourist destination. Also, Slovenian Alps are among the most developed tourism regions in Slovenia. Tourism in this area has a long tradition although it begun to attract larger numbers of visitors only in the second half of the $20^{\text {th }}$ century.

The aim of the paper was to find out how residents perceive positive and negative impacts of tourism in Slovenian alpine areas and how their perception of these impacts influence their attitude toward tourism and future tourism development. To acquire necessary data, a 
questionnaire survey was undertaken in five alpine tourist resorts. We have chosen resorts with different characteristics of tourism development and with different levels of tourist visitation.

The results of the survey have showed which positive and negative impacts of tourism development are more important, according to the opinion of local population. Despite the differences between tourist resorts where surveys were undertaken, many similar characteristics have been found out. We should mention generally positive attitude towards tourism and the fact that economic effects are perceived as the most important and the sociocultural ones as the least important.

The local population perceives numerous positive tourism impacts. Among them the most apparent are the ones related to the efforts to improve visual appearance of the resort and quality of environment, followed by tourism related economic benefits, but among them the employment opportunities are not in the foreground. Most of residents perceive positive impacts of tourism on the quality of living, which can be seen in better leisure opportunities and improved quality of services. On the other hand, the most important negative impacts of tourism are the economic ones. The local population is affected by the increased costs of living (housing, food, etc.). Beside that local population is troubled by various everyday inconveniences, which are related predominantly to the increased visitation in the high season (traffic jams, noise, queues in the shops, etc.). Other negative impacts are generally less important. Local inhabitants expect from the tourism important economic benefits and feel that they, to the large extent, depend on it. Beside that tourism also contributes to improved quality of living (e.g. improved services, infrastructure). Because of that, they attribute lesser importance to its negative impacts and consequently evaluate tourism as a whole more positively. Important role of economic viewpoint in evaluation of tourism is also the consequence of lesser importance of other economic alternatives. Beside that, due to the remoteness of larger centres, other employment opportunities are not easily accessible.

Results show that local population perceives tourism impacts on improved quality of living especially in the resorts with more developed tourism, where its positive impacts are distributed among wider strata of population. On the other hand its negative impacts are deemed important only in the case of intensive tourism development. They are perceived more negatively when the local population feels that there are no real benefits from tourism.

The positive attitude of local population towards tourism and its impacts in the Slovenian alpine areas was also revealed by some other researches, e.g. results of questionnaire survey in Bohinj (Maraž, 2007) or the questionnaire survey performed during fieldwork of the geography students in the years 2005 and 2006 (Delovno gradivo 2005-2006) in various alpine tourist resorts. We can conclude that tourism in Slovenian alpine areas has not yet attained such a level of tourism development which would cause important negative attitudes among local population.

There are marked differences in tourism impacts among various areas. Intensity and character of the tourism impacts depend on numerous factors which are area-specific and thus indirectly influence perception of local population. They are related also to the characteristics of tourists and tourism supply and to the speed and intensity of tourism development. Similar research, performed in the area with more developed tourism, would most probably produce 
different findings. This is indicated also by findings of research undertaken in Piran (Tkalčič 2006), where opinion of local population about tourism is much less positive.

The research pointed out some problematic dimensions of tourism development in Slovenian alpine areas. The future tourism development, which is advocated also by local population, will put additional demands on transport and communal infrastructure and it would increase environmental pressures. Without proper treatment of related problems the support of local population to tourism development will diminish.

(Translated by the author) 